\title{
Path Analysis: Application of Health Belief Model on the Determinants of Clean and Healthy Behavior among Elderly with Hypertension
}

\author{
Septian Najib Imtichan'), Didik Tamtomo²), Endang Sutisna Sulaeman²) \\ 1)Masters Program in Public Health, Universitas Sebelas Maret \\ ${ }^{2)}$ Department of Public Health, Faculty of Medicine, Universitas Sebelas Maret
}

\begin{abstract}
Background: Lifestyle or behavioral factors critically determine high blood pressure in individuals. Elderly with hypertension in Indonesia aged $55-64$ years by $45.9 \%$, 65-74 years by $57.6 \%$, and $>75$ years by $63.8 \%$. This study aimed to examine factors affecting healthy behavior in elderly with hypertension using health belief model.

Subjects and Method: This was a cross sectional study conducted in Ngawi, East Java, from June to July 2019. A sample of 200 elderly was selected by multistage random sampling. The dependent variable was clean and healthy behavior. The independent variables were perceived susceptibility, perceived severity, perceived benefit, cues to action, self-efficacy, knowledge, attitude, and access to health service. The data were collected by questionnaire and analyzed by path analysis.

Results: Clean and healthy behavior was positively and directly affected by self-efficacy $(b=1.51$; $95 \% \mathrm{CI}=0.29$ to $2.74 ; \mathrm{p}=0.015)$, attitude $(\mathrm{b}=2.37 ; 95 \% \mathrm{CI}=1.17$ to $3.56 ; \mathrm{p}<0.001)$, cues for action $(\mathrm{b}=2.48 ; 95 \% \mathrm{CI}=1.11$ to $3.86 ; \mathrm{p}<0.001)$, perceived susceptibility $(\mathrm{b}=2.07 ; 95 \% \mathrm{CI}=0.89$ to 3.26 ; $\mathrm{p}=0.001)$, perceived severity $(\mathrm{b}=1.76 ; 95 \% \mathrm{CI}=0.54$ to $2.99 ; \mathrm{p}=0.005)$, perceived benefit $(\mathrm{b}=1.47$; $95 \% \mathrm{CI}=0.36$ to $2.57 ; \mathrm{p}=0.009)$, and access to health services $(\mathrm{b}=2.26 ; 95 \% \mathrm{CI}=1.00$ to 3.53 ; $\mathrm{p}<0.001)$. Clean and healthy behavior was indirectly affected by knowledge.

Conclusion: The clean and healthy lifestyle behavior of the elderly is directly affected by perceived vulnerability, perceivedseverity, perceivedbenefits, cues to act, self-efficacy, attitudes and access to health services. Clean and healthy behavior is affected by knowledge.
\end{abstract}

Keywords: clean and healthy behavior, elderly, health belief model, path analysis

\section{Correspondence:}

Septian Najib Imtichan. Masters Program in Public Health, Universitas Sebelas Maret, Jl. Ir. Sutami 36A, Surakarta 54176, Central Java. Email: septianimtichan@gmail.com. Mobile: $+6285229799672$

\section{BACKGROUND}

One indicator of the success of the health development program is an increase in the life expectancy of Indonesian population. Central Agency on Statistics(BPS) reports the results of Intercensal Population Surveys (SUPAS) in2015 which stated that life expectancy in Indonesia at 72.1 years, meaning that every child born will have an average life expectancy until 72.1 years old (Statistics Indonesia, 2017).
Unhealthy lifestyles in the elderly population in Indonesia cause an increase in the percentage of elderly with health issues or morbidity rate for the elderly. The elderly morbidity rate in 2018 was $25.99 \%$. It means that from 100 elderly there were 25 to 26 elderly with health issues (Statistics Indonesia, 2018).

Changes in the elderly in developed countries have a physical impact on the elderly. These impacts include changes in the cardiovascular system which is a major 
disease of the elderly which affects other diseases such as hypertension, coronary heart disease, pulmonic heart disease, cardiomyopathy, stroke and kidney failure (Fatma, 2010).

Elderly hypertension patients in Indonesia aged $55-64$ years by $45.9 \%$, aged $65-74$ years by $57.6 \%$, and aged $>75$ years by $63.8 \%$. The prevalence of hypertension in Indonesia based on the diagnosis of doctors in the population aged $>18$ years by $8.4 \%$ (Ministry of Health of the Republic of Indonesia, 2018). Whereas in Ngawi Regency, East Java, 10,042 cases of hypertension were reported and served at the Community Health Center (Ngawi Health Office, 2016).

In understanding correct lifestyle practices and in order to avoid disease, individuals and society need to learn the right behavior. In this case, the Health Belief Model (HBM) is the first theory in the field of health related to health behavior. HBM can explain prevention behavior and individual response to disease. HBM confirms that a person's perceived vulnerability and efficacy of treatment can affect a person's decision on behavior towards his health (Janz et al., 1984).

This study was conducted to determine the determinants of clean and healthy behavior in the elderly with hypertension by applying the Health Belief Model theory.

\section{SUBJECTS AND METHOD \\ 1. Study Design}

This study was an observational analytic study with Cross Sectional design. This study was conducted in Ngawi, East Java, from June to July 2019.

\section{Population and Samples}

The target population in this study was elderly with hypertension in Ngawi, East Java, amounted to 512 people. A sample of
200 elderly was selected by multistage random sampling.

\section{Study Variables}

The dependent variable was clean and healthy behavior. The independent variables were perceived susceptibility, perceived severity, perceived benefit, cues for action, self-efficacy, knowledge, attitude, access to health services, and family support.

\section{Operational Definition of Variables}

Clean and healthy life behavior was an activity carried out by humans and can be seen immediately within a certain time to maintain and improve health status of individuals.

Perceived susceptibility was a subjecttive perception of a person about the risk of contracting the disease, and the perceived possibility refers to a person's risk of certain diseases or adverse health effects. The measuring instruments in this study was questionnaires with continuous data scale. For analytical purposes, continous data was converted to dichotomous.

Perceived Severity was the perceived seriousness or severity of the disease. It also left the disease untreated (including evaluation of both medical and clinical consequences and social consequences that may arise) according to circumstances or actions that may occur. The measuring instruments in this study was questionnaire with continous data scale. For analytical purposes, continous data was converted to dichotomous.

Perceived benefit was someone who feels the benefits gained when paying for health facilities and services when compared to the risk of his illness. The measuring instruments in this study was questionnaire with continous data scale. For analytical purposes, continous data was converted to dichotomous. 
Cues to action was a stimulus for action or stimulation needed to trigger the decision making process so that health behavior occured. The measuring instrument in this study was questionnaires with continous scale. For analytical purposes, it was converted to dichotomous.

Self-Efficacy was belief in one's own ability to do things. Self-efficacy could be seen as a person's belief about the extent to which he was able to control motivation, behavior, and social environment. This was necessary to produce a behavior. The measuring instrument in this study was questionnaires with continous data scale. For analytical purposes, continous data was converted to dichotomous.

Knowledge was the result of "knowing" and this happened after the person senses a certain object. The measuring instruments in this study wasquestionnaires with continous data scale. For analytical purposes, it was converted to dichotomous.

Attitude was readiness or willingness to act, and was not an implementation of certain motives. The measurement scale was continous. For data analysis, it was transformed into dichotomous.

Access to Health Services. At every time that was needed, to behave in a healthy manner, the community needed supporting facilities and infrastructure. The measurement scale was continous. For data analysis, it was transformed into dichotomous.

Family Support was a form of service behavior performed by the family in the form of emotional support, appreciation, information and instrumental support. The measurement scale was continous. For data analysis, it was transformed into dichotomous.

\section{Data Analysis}

This study used path analysis with steps which included model specifications, model identity, model suitability, parameter estimation, and model respesification.

\section{Research Ethics}

The research ethics used were informed consent, anonymity, confidentiality, justice, benefit, and ethical clearance from the Health Research Ethics Committee of the Faculty of Medicine, Sebelas Maret University, Surakarta, (No. 12 / KEPK / 2019).

\section{RESULTS \\ 1. Distribution of Subjects of the Study}

In the univariate analysis the results of the distribution of the study subjects showed clean and healthy behavior as in table 1 .

\section{Path Analysis}

The path analysis model observed the effect of 9 variables, namely 3 endogenous variables and 6 exogenous variables. Degree of freedom (df) which showed the path analysis could be done. The formula of degree of freedom is as follows: $\mathrm{df}=$ (number of measured variables $\mathrm{x}$ (number of measured variables +1 ) / 2- (endogenous variables + exogenous variables + number of parameters) with the value $\mathrm{df}=$ $(9 \mathrm{x}(9+1) / 2-(3+6+9)=(90 / 2)-18=$ $45-18=27$. Path analysis can be done if $\mathrm{df}$ $\geq 0$. The specification of the model will illustrate the effectof the variables to be examined.

Table 2 shows that self-efficacy had a direct and positive effect on clean and healthy behaviors. The elderly with high self-efficacy had a logodd of 1.51 units higher $(\mathrm{b}=1.51 ; 95 \% \mathrm{CI}=0.29$ to $2.74 ; \mathrm{p}=$ o.015) than low self-efficacy.

There was a direct and positive effectof attitude on clean and healthy behavior. Elderly with good attitude had a logodd of 2.37 units higher $(b=2.37 ; 95 \%$ $\mathrm{CI}=1.17$ to $3.56 ; \mathrm{p}<0.001$ ) than the elderly with poor attitude. 
Tabel 1. Sample characteristics

\begin{tabular}{lcc}
\hline Characteristics & n & Percentage \\
\hline Perceived Vulnerability & 126 & 63.0 \\
Low & 74 & 37.0 \\
High & 109 & 54.5 \\
Perceived Severity & 91 & 45.5 \\
Low & & 61.0 \\
High & 122 & 39.0 \\
Perceived Benefit & 78 & 51.0 \\
Low & & 48.0 \\
High & 103 & \\
Cue to action & 97 & 54.0 \\
Low & & 46.0 \\
High & 108 & 60.0 \\
Self-efficacy & 92 & 40.0 \\
Low & & \\
High & 120 & 67.0 \\
Knowledge & 80 & 33.0 \\
Poor & & \\
Good & 134 & 48.5 \\
Attitude & 66 & 51.5 \\
Poor & & 48.5 \\
Good & 97 & 51.5 \\
Health Care Access & 103 & 75.0 \\
Difficult & 97 & 25.0 \\
Family support & 103 & \\
Weak & 150 & \\
Strong & 50 & \\
Clean and Healthy Behavior & & \\
Poor & & \\
Good & & \\
\hline
\end{tabular}

There was a direct and positive effect of cues to acttionon clean and healthy behavior. Elderly with a high cues to action had a logodd of 2.48 units higher $(b=2.48$; 95\% $\mathrm{CI}=1.11$ to $3.86 ; \mathrm{p}<0.001$ ) than elderly with a low cues to action.

Perceived vulnerability had a direct and positive effect on clean and healthy behavior. Elderly with a high perceived vulnerability had a logodd of 2.07 units higher $(\mathrm{b}=2.07 ; 95 \% \mathrm{CI}=0.89$ to $3.26 ; \mathrm{p}=$ o.001) than low perceived vulnerability.

There was a direct and positive effect of perceived severity on clean and healthy behavior. The elderly with high perceived severity had a logodd of 1.76 units higher $(b=1.76 ; 95 \% \mathrm{CI}=0.54$ to $2.99 ; \mathrm{p}=0.005)$ than the elderly with low perceived severity. There was a direct and positive effect of perceived benefits on clean and healthy behavior. Elderly with high perceived benefit had a logodd of 1.47 units higher $(b=$ 1.47; $95 \% \mathrm{CI}=0.36$ to $2.57 ; \mathrm{p}=0.009$ ) than elderly with low perceived benefit.

Access to health services was directly and positively related to clean and healthy behaviors. Elderly with easy access to health services had a logodd of 2.26 units higher $(b=2.26 ; 95 \% \mathrm{CI}=1.00$ to 3.53 ; $\mathrm{p}$ $<0.001$ ) than older people with difficult access to health services.

Knowledge was indirectly related to clean and healthy behavior through per- 
Journal of Health Promotion and Behavior (2019), 4(2): 110-120

https://doi.org/10.26911/thejhpb.2019.04.02.03

ceived vulnerability. Elderly with good knowledge had a logodd for the high perceived vulnerability of 0.92 units higher ( $\mathrm{b}=0.92 ; 95 \% \mathrm{CI}=0.33$ to $1.52 ; \mathrm{p}=0.002$ ) than elderly with poor knowledge.
Knowledge was indirectly related to clean and healthy behavior through attitude. Elderly with good knowledge had a logodd for good attitude of 1.12 units higher ( $b=$ 1.12; $95 \% \mathrm{CI}=0.50$ to $1.74 ; \mathrm{p}<0.001$ ) than elderly with poor attitude.

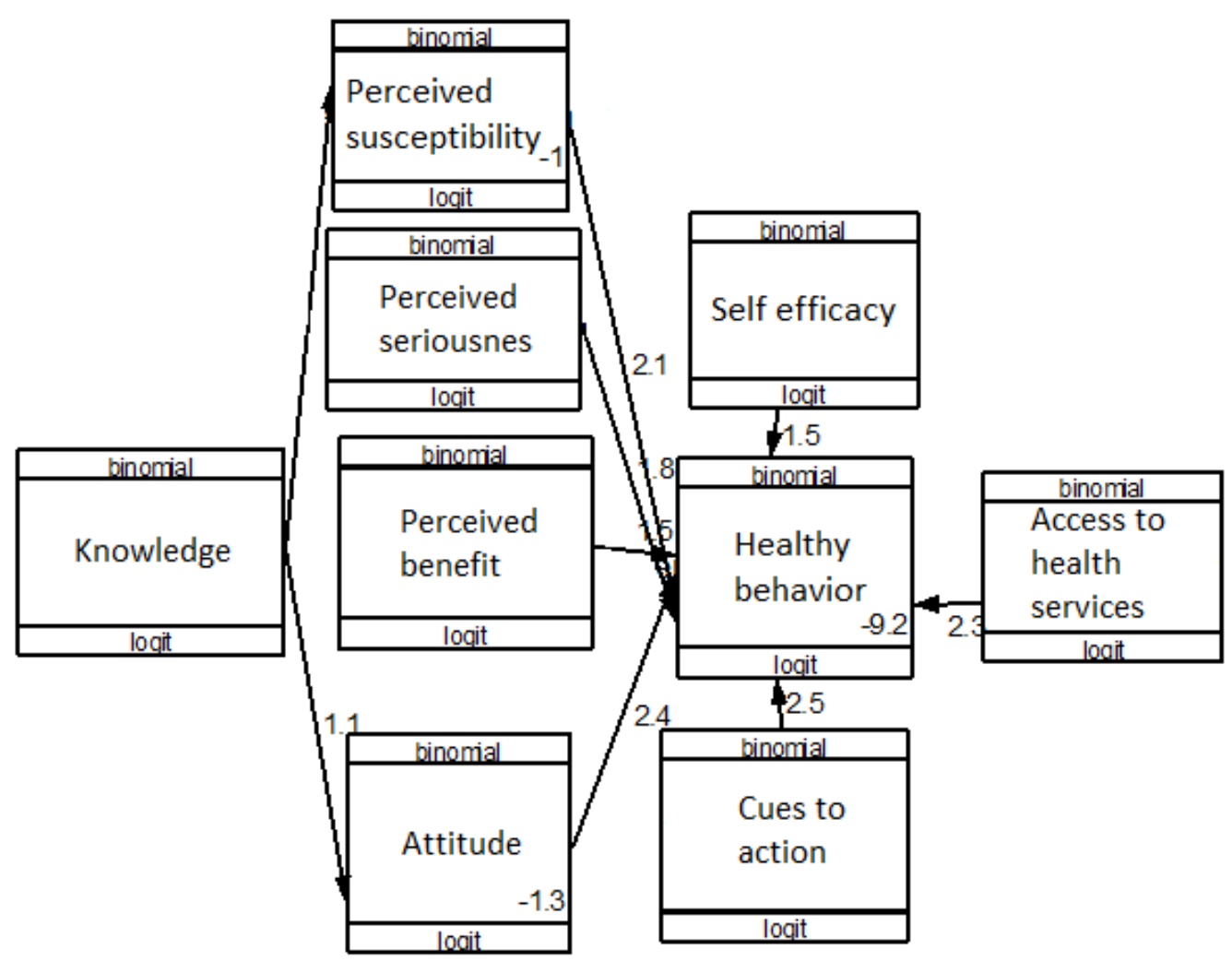

Figure 1. Structural model of path analysis with estimation

Table 2. Results of analysis of determinants of clean and healthy behavior: application of health belief model theory

\begin{tabular}{|c|c|c|c|c|c|}
\hline \multirow{2}{*}{ Dependent variable } & \multirow[b]{2}{*}{ Independent variable } & \multirow[b]{2}{*}{ b } & \multicolumn{2}{|c|}{ 95\% CI } & \multirow[b]{2}{*}{$\mathbf{p}$} \\
\hline & & & $\begin{array}{c}\text { Lower } \\
\text { limit }\end{array}$ & $\begin{array}{l}\text { Upper } \\
\text { limit }\end{array}$ & \\
\hline \multirow{8}{*}{$\begin{array}{l}\text { Direct effect } \\
\text { Clean and Healthy } \\
\text { Behavior }\end{array}$} & & & & & \\
\hline & $\leftarrow$ Self-efficacy (High) & 1.51 & 0.29 & 2.74 & 0.015 \\
\hline & $\leftarrow$ Attitude (Good) & 2.37 & 1.17 & 3.56 & $<0.001$ \\
\hline & $\leftarrow$ Cues to action (High) & 2.48 & 1.11 & 3.86 & $<0.001$ \\
\hline & $\begin{array}{l}\leftarrow \text { Perceived vulnerability } \\
\text { (High) }\end{array}$ & 2.07 & 0.89 & 3.26 & 0.001 \\
\hline & $\leftarrow$ Perceived severity (High) & 1.76 & 0.54 & 2.99 & 0.005 \\
\hline & $\leftarrow$ Perceived benefit(High) & 1.2 & 0.36 & 2.57 & 0.009 \\
\hline & $\leftarrow$ Health care access (Easy) & 2.26 & 1.00 & 3.53 & $<0.001$ \\
\hline \multirow{2}{*}{$\begin{array}{l}\text { Indirect Effect } \\
\text { Perceived susceptibility } \\
\text { (High) }\end{array}$} & & & & & \\
\hline & $\leftarrow$ Knowledge (Good) & 0.92 & 0.33 & 1.52 & 0.002 \\
\hline $\begin{array}{l}\text { Attitude }(\text { Good }) \\
\text { N Observation }=200 \\
\text { Log likelihood }=-293.1\end{array}$ & $\leftarrow$ Knowledge (Good) & 1.12 & 0.50 & 1.74 & $<0.001$ \\
\hline
\end{tabular}




\section{DISCUSSION}

\section{Effect of knowledge on clean and healthy behavior}

The results of this study indicate that there was an indirect and positive effectof knowledge on clean and healthy behavior through perceived vulnerability and attitude and it was statistically significant. Elderly who had good knowledge were more likely to engage in clean and healthy behavior than elderly with poor knowledge. The lack of knowledge of the elderly can be seen from respondents who did not understand about clean and healthy behavior, factors causing the elderly to get hypertension, and what is meant by hypertension itself. This shows that health promotion regarding the importance of clean behavior and hypertension is not given optimally.

This result is in line with the study by Prihanti et al. (2018), which showed that respondents with low knowledge will find it difficult to apply clean and healthy behavior. The study showed that poor knowledge had an impact on clean and healthy behaviors by 0.079 times compared to those who had good knowledge.

The results of this study are also in line with the study of Masyudi (2018), which proved that there was a significant effect of knowledge on behavioral prevention of hypertension by the elderly.

Knowledge is the most influential factor in the formation of attitudes and behaviors. The existence of knowledge will make it easier to accept new behaviors or behavior changes based on good knowledge, awareness, and positive attitude (Fitrianiet al., 2018).

Knowledge based on the Health Belief Model improves health behaviors and beliefs about hypertension in the elderly population with hypertension (Khorsandi et al., 2017).
So, henceforth the elderly will do blood pressure checks regularly and on time as a form of solving these health problems.

\section{The effect of attitude on clean and healthy behavior}

The results of this study indicated that there was a direct and positive effectof attitudes on clean and healthy behaviors and was statistically significant. Elderly who have good attitudes will affect the intention or desire to conduct clean and healthy behavior and routinely conduct blood pressure checks at the integrated services post and the nearest health centers.

The results of this study are in line with the study of Mindianata (2018), which proved that there is a significant effect of attitude on active intention to follow integrated services post. The results of the study showed a value $(\mathrm{p}=0.008)$.

Based on a study conducted by Ogilvie et al. (2015), attitude can affect one's intention to conduct an early examination of cervical cancer detection. The accuracy of the examination, safety, the ability of the examination in protecting health, and acceptance of screening affect a person's positive judgment and positive attitude towards early detection of cervical cancer.

It is similar with a studywith attitude variables that can effect behavior conducted by Annisa et al. (2019) which stated that attitudes can affect preventive actions for osteoporosis. This study showed value $(\mathrm{r}=$ $0.22 ; \mathrm{p}=0.017$ ). But in theory attitude will provide a basis for someone to behave in a certain way (Wardhani et al., 2017).

\section{The effect of access to health services on clean and healthy behavior}

The results of this study indicated that there was a direct and positive effect of access to health services on clean and 
healthy behavior and was statistically significant.

The results of this study are in line with a study by Nainggolan et al., (2016), which proved that there is a positive effect of access to health services on the completeness of immunization of children under two years. The study showed that respondents who have a long time service in health facilities have a risk of incomplete immunization of 1.33 times compared to fast service time. While the statistical test showed that difficulty in getting transportation causes give the risk of incomplete immunization status by 1.49 times compared to respondents who can get transportation easily to health facilities (Nainggolan et al., 2017).

The distance of the services that can be reached by the community will increase the utilization of health facilities, because distance limits a person's ability and willingness to seek services. Especially if transportation is limited, communication is difficult, and there are no services in the area, it is necessary to provide complete health facilities and reach out to areas so that health services are easily accessible for the community (Sarinastiti et al., 2018).

This study is in accordance with a study conducted by Karman et al. (2016) which suggested that access can affect the frequency of visits to health facilities. The closer the residence to the health care center, the greater the number of visits to the health care center. And vice versa, the farther the distance of residence with the health service center the smaller the number of visits at the health center.

\section{The effect of perceived susceptibi- lity on clean and healthy behavior}

The results of this study indicated that there was a direct and positive effect of perceived vulnerability on clean and healthy behaviors and was statistically significant. The low perception was due to the lack of elderly knowledge of the dangers of hypertension and the importance of clean and healthy behavior. So, they did not feel that they were vulnerable to complications from complications that begin with hypertension and did not engage in clean and healthy behavior.

The results of this study are in line with the studyby Attamimy and Qomaruddin (2017), which proved that there was an effectofperceived vulnerability and DHF prevention behavior.

The study shows a result of $b=0.29$ which means that individuals who have a high perceived vulnerability will increase prevention behavior by 0.29 units higher than those with a low perceived vulnerability. Besides, the value of a positive relationship shows a relationship that was directly proportional. This means that if the individual considers himself more vulnerable, the better it is to make an effort to live a healthy life (Attamimy and Qomaruddin, 2018).

Cues to action are needed to encourage individual involvement in health behavior. Cues to action can come from internal and external factors. Internal factors include physiological cues for symptoms or health complaints. External factors such as information from family friends, health workers, media, etc. (Setiyaningsih et al., 2016).

Perceived vulnerability refers to subjective assessment of risks to health problems. Someone who feels at low risk for an illness, then the possibility of conducting unhealthy behavior is higher. Conversely, if someone feels themselves at risk for an illness he will be more likely to reduce that risk (Onoruoiza et al., 2015).

Likewise, the elderly who realize that they are vulnerable or at risk of developing hypertension will make an effort to prevent 
the disease by carrying out clean and healthy behavior. As stated by the Health Belief Model theory developed by Rosenstock (1994) cited in Murti (2018) that the presumption of a person to be exposed to an illness will make themselves aware to do a prevention and protection.

A study by Bakhtari et al. (2012) suggested that someone who considers themselves vulnerable to health problems will take action to protect themselves.

The Health Belief Model predicts that a person who has perceived vulneabilirty to a disease tend to prevent the occurrence of the disease. Conversely, someone who has a low perceived vulnerability to disease has a lower tendency of taking the actions to prevent the occurrence of the disease. The individual is more likely to engage in unhealthy behavior or risky behavior (Murti, 2018).

\section{Effect of perceived severity on clean and healthy behavior}

The results of this study indicated that there was a direct and positive effect ofperceived severity on clean and healthy behavior and was statistically significant.

The results of this study are in line with the studyconducted by Attamimy and Qomaruddin (2018) which proved that there was a positive effectofperceived severity on DHF prevention behavior. The study showed that respondents who had high perceived severity would increase prevention behavior by 0.406 units higher than respondents who had low perceived severity. Thus, the relationship between these variables was strong. While a positive value on the coefficient indicated the relationship between variables was directly proportional. This means that if perceived vulnerability is high, the greater the prevention behavior. Conversely, the smaller perceived severity, the worse the prevention behavior is carried out.
Perceived severity refers to a person's subjective assessment of the severity of a disease, as well as the potential that can be caused if it is not treated or prevented. Someone who considers that a disease is a serious disease will be more likely to take an action that is needed to prevent the occurrence of the disease, or reduce its severity (Murti, 2018).

The perceived seriousness construction concerns an individual's beliefs about the seriousness or severity of the disease. Meanwhile, perceived seriousness is often based on medical information or knowledge, it can also come from a person's belief that he will get into trouble due to illness and will have an effect on his life (Sulaeman 2016).

Perceived severity of an illness will affect beliefs about the disease itself. Trust in one's ability is the key to influencing changes in health behavior (Shojaei et al., 2016).

\section{The effect of perceived benefits with clean and healthy behavior}

The results of this study indicate that there is a direct and positive effect of perceived benefits on clean and healthy living behavior and is statistically significant.

The results of this study are in line with the study of Attamimy and Qomaruddin (2017), which proves that there is a positive effectofperceived benefits on DHF prevention behavior.

The study shows that respondents who have a high perceived benefits will increase prevention behavior compared with respondents who have a low perceived benefits. In addition, positive values on the coefficients describe a directly proportional relationship. This means that the greater perceivedbenefits perceived by the subject of the study, the better the prevention behavior, and vice versa (Attamimy and Qomaruddin, 2018). 
If an individual believes that certain actions will reduce vulnerability to health problems or reduce seriousness, then he tends to engage in behavior regardless of objective facts regarding the effectiveness of the action. This is also reinforced by the HBM theory which states that healthrelated behavior is also influenced by a person's perceivedbenefits of taking healthy actions or behaviors. The perceived benefits of a person will affect preventive action (Murti, 2018).

The construction of perceived benefits is one's opinion of the usefulness of a new behavior in reducing the risk of disease. Individuals tend to be healthier when they believe that new behavior will reduce their chances of developing the disease. Perceived benefits play an important role in determining behavior for secondary prevention (Attamimy and Qomaruddin, 2018).

The perceived benefits will affect one's judgment to behave to reduce risk or take precautions. If someone believes in certain actions that can reduce the susceptibility of a disease, then he will tend to be involved (Onoruoiza et al., 2015).

\section{The effect of cues to actionon clean and healthy behavior}

The results of this study indicated that there was a direct and positive effect of the cues to act on clean and healthy behavior and it was statistically significant.

The results of this study was in line with a study by Kurniawati and Sulistyowati (2014), which proved that there is a positive effect of the cues of action on health prevention behavior.

This study showed that respondents who had a strong cue to action will increase the behavior of vaginal discharge prevention efforts by 0.621 times compared to respondents who have a weak cue to action (Kurniawati and Sulistyowati, 2014).
Cues to action are needed to encourage individual involvement in health behavior. Cues to action can come from internal and external factors. Internal factors include physiological cues for symptoms or health complaints. External factors such as information from family friends, health workers and the media, etc. (Setiyaningsih et al., 2016).

HBM shows that behavior is also influenced by cues to action. Cues to action can improve one's healthy behavior with significant results. The effectiveness of HBM increases bone density to prevent osteoporosis (Jeihooni et al., 2016).

\section{Effect of self-efficacy on clean and healthy behavior}

The results of this study indicated that there was a direct and positive effect of selfefficacy on clean and healthy behaviors and was statistically significant.

The results of this study are in line with the study by Setiyaningsih et al. (2016), which proved that there is a direct and positive effectof self-efficacy on hypertension prevention behavior $(\mathrm{b}=0.11 ; \mathrm{SE}=$ 0.02; $\mathrm{p}<0.001$ ).

Increasing one's self-efficacy can improve one's health behavior as well as in compliance with taking anti hypertensive drugs (Yueet al., 2015). Someone generally does not try to do something new unless they can do it. If someone believes that a new behavior is useful (perceived benefits), but thinks he is unable to do (perceived resistance), chances are he will not do a behavior. Variations of this model are perceived values and interventions determined as main beliefs (Murti, 2018).

\section{AUTHOR CONTRIBUTIONS}

Septian Najib Imtichan, main author whose role was in collecting and processing the data of the study. Didik Tamtomo did data analysis. Endang Sutisna Sulaeman 
examined the conceptual framework and methodology.

\section{FUNDING AND SPONSORSHIP}

This study used independent fund.

\section{CONFLICT OF INTEREST}

There is no conflict of interest.

\section{ACKNOWLEDMENT}

We would like to express our gratitude to the Health Office, Health Centers, and health cadres in Ngawi for helping us in this study.

\section{REFERENCE}

Annisa NN, Hidajat NN, Setiawati EP (2019). Hubungan pengetahuan dan sikap dengan tindakan pencegahan osteoporosis pada remaja puteri di Kecamatan Soreang, Kabupaten Bandung. Jur-nal Sistem Kesehatan, 4(3): 110-116. http://journal.unpad.ac.id/jsk_ikm/article/view/21239/10013

Attamimy HB, Qomaruddin MB (2018). Aplikasi health belief model pada perilaku pencegahan demam berdarah dengue. Jurnal PROMKES, 5(2): 245. https://doi.org/10.20473/jpk.v5.i2.2017.245-255.

Badan Pusat Statistik (2017). Statistik penduduk lanjut usia 2017.Badan Pusat Statistik. https://www.bps.go.id/QuickMap?id=00000000. doi.org/04220.1801

Bakthari AF, Nuri ZR, Suhebi L (2012). Effect of education based on health belief model on believe promotion and screening behaviours of breast cancer among women reffered to tabriz health centers. Medl J Tabriz Uni Medl Sci. 33: 25-31.

Fatma (2010). Gizi usia lanjut. Jakarta: Penerbit Erlangga.
Fitriani Y, Mudigdo A, Andriani RB (2018). Health belief model on the determinants of human papilloma virus vaccination in women of reproductive age in surakarta, central java.Journal of Health Promotion and Behavior, 3(1): 16-26. https://doi.org/10.26911/thejhpb.2018.03.01.02.

Janz NK, Becker MH, Associate R, Becker Is Professor $\mathrm{MH}$ (1984). The health belief model: a decade later reprint requests to. Health education quarterly, 11(1): 1-47. https://journals.sagepub.com/doi/pdf/10.1177/109019818401100101.

Jeihooni A, Hidarnia A, Kaveh M, Hajizadeh E, Askari A (2016). Application of the health belief model and social cognitive theory for osteoporosis preventive nutritional behaviors in a sample of iranian women.Iranian Journal of Nursing and Midwifery Research, 21(2): 131. https://doi.org/10.4103/1735-9066.178231

Karman, Sakka A, Saputra SK (2016). Faktor-faktor yang berhubungan dengan pemanfaatan pelayanan kesehatan bagi masyarakat pesisir di desa bungin permai kecamatan tinanggea kabupaten konawe selatan tahun 2016.Jurnal Ilmiah Mahasiswa Kesehatan Masyarakat Unsyiah, 1(3): 1-9. http://ojs-uhoac.id/index.php/jimkesmas/article/view/1224/871.

Kementerian Kesehatan Republik Indonesia (2016). Data dan informasi profil kesehatan indonesia 2016. Pusat Data Dan Informasi Kementerian Kesehatan RI. Retrieved from http://depkes.go.id/resources/download/pusdatin/lain-lain.

Khorsandi M, Fekrizadeh Z, Roozbahani N (2017). Investigation of the effect of education based on the health belief model on the adoption of hyper- 
tension controlling behaviors in the elderly. Clinical Interventions in Aging, 12: 233-240. https://www.ncbi.nlm.nih.gov/pmc/articles/PMC5291452/doi.org/10.2147/CIA.S117142.

Kurniawati C, Sulistyowati M (2014). Aplikasi teori health belief model dalam pencegahan keputihan patologis. Promosi Kesehatan Dan Ilmu Perilaku, Jurnal Promkes, (2): 123-125.

Masyudi M (2018). Faktor yang berhubungan dengan perilaku lansia dalam mengendalikan hipertensi. Action: Aceh Nutrition Journal, 3(1): 57. https://doi.org/10.30867/action.v3i1.100.

Nainggolan O, Hapsari D, Indrawati L (2017). Pengaruh akses ke fasilitas kesehatan terhadap kelengkapan imunisasi baduta (analisis riskesdas 2013). Media Penelitian Dan Pengembangan Kesehatan, 26(1): https://doi.org/10.22435/mpk.v26i1.4900.15-28.

Ogilvie GS, Smith LW, Niekerk DJV, Khurshed F, Krajden M (2015). Women's intentions to receive cervical cancer screening with primary human papillomavirus testing. HHS Public Access. Int J Cancer, 133 (12): 2934-2943. Doi:10.1002/ijc.28324.

Onoruoiza SI, Musa, Umar BD, Kunle. (2015). Using health beliefs model as an intervention to non compliance with hypertension information among hypertensive patient. International Organization of Scientific Research Journal Of Humanities And Social Science, 20(9): 11-16. https://doi.org/10.9790/0837-20951116

Prihanti GS, Lisda DA, Artsinta II, Hanggara SP, Galih RP, Sinta F (2018). Faktor-faktor yang mempengaruhi tingkat perilaku hidup bersih dan sehat pada tatanan rumah tangga di wilayah kerja puskesmas poned $\mathrm{x}$. Saintika Medika, 14(1). https://doi.org/10.22219/sm.vol14.smumm1.6644.

Sarinastiti R, Fajriyanto AN, Prabumukti DR, Insani MK, Aziz WN, Fortuna LD, Khoirunisa N (2018). Analisis pengetahuan perilaku hidup sehat dan pemanfaatan puskesmas. Promotif: Jurnal Kesehatan Masyarakat,8(1): 61. https://doi.org/10.31934/promotif.v8i1.231

Setiyaningsih R, Tamtomo D, Suryani N (2016). Health belief model: determinants of hypertension prevention behavior in adults at community health center, sukoharjo, Central Java. Journal of Health Promotion and Behavior, 1(3): 160-170. https://doi.org/10.26911/thejhpb.2016.01.03.03.

Shojaei S, Farhadloo R, Aein A, Vahedian M (2016). Effects of the health belief model (hbm)-based educational program on the nutritional knowledge and behaviors of cabg patients. Journal of Theran University Heart Center, 11(4): 181-186.

Wardhani GK, Mudigdo A, Qadrijati I (2017). Path analysis on the determinants of pap smear utilization for cervical cancer early detection in women of reproductive age.Journal of Health Promotion and Behavior,2(4): 359-370. https://doi.org/10.26911/thejhpb.2017.02.04.08

Yue Z, Li C, Weilin Q, Bin W (2015). Application of the health belief model to improve the understanding of antihypertensive medication adherence among Chinese patients. Patient Education and Counseling, 98(5): 669673. https://doi.org/10.1016/j.pec.2015.02.007 